\title{
DENSITY VARIATIONS IN ALPINE SNOW
}

\author{
By Donald Alford* \\ (Department of Geology, University of British Columbia, Vancouver, Canada)
}

\begin{abstract}
Stratigraphic studies of the annual snow layer in the Beartooth Mountains of south-western Montana and on Mount Logan in the St. Elias Range have disclosed a similiar distribution of at least one physical property of the snow pack in the two areas. The average density of the pack, obtained by integrating a series of measurements taken at $5^{-10} \mathrm{~cm}$. vertical intervals over the total thickness of the annual layer, reaches a maximum value near a mid-point of the total elevation covered by each traverse and decreases linearly toward the elevation extremes. A preliminary hypothesis, relating the distribution of average snow-density values along slopes to a semi-stable zonation of near-surface air temperatures, is presented.
\end{abstract}

RÉsumÉ. Variations de densité de la neige alpine. Les études stratigraphiques de la couche annuelle de neige dans les Beartooth Mountains (S-W Montana) et dans Mount Logan (St. Elias Range) ont permis de séparer une distribution similaire d'aumoins une seule propriété physique de la couche de neige des deux zones. La densité moyenne de la couche, obtenue par intégration d'une série de mesures faites en des intervalles verticaux de $5^{-10} \mathrm{~cm}$ à travers toute la couche annuelle, atteint un maximum proche d'un point moyenne de l'élévation totale couverture par chaque traverse et décroît linéairement vers les élévations extrêmes. Une hypothèse préliminaire, liant la distribution des valeurs moyennes de la densité de la neige le long des pentes à la une semi-stable zonation des températures de l'air proches de la surface, est présentée.

Zusammenfassung. Dichteschwankungen in alpinem Schnee. Stratigraphische Untersuchungen der Jahresschicht des Schnees in den Beartooth Mountains in Südwest-Montana (U.S.A.) und am Mount Logan in der St. Elias Range (Kanada) zeigten in den beiden Gebieten für mindestens eine physikalische Eigenschaft des Schnees eine ähnliche Schwankung. Die mittlere Schneedichte-als arithmetisches Mittel aus Serienmessungen in je $5-10 \mathrm{~cm}$ Abstand durch die ganze Schneeschicht - erreicht ihr Maximum ungefähr in der mittleren Meereshöhe der untersuchten Profile und nimmt gegen die extrem hohen oder tiefen Lagen hin linear ab. Es wird eine vorläufige Hypothese aufgestellt, wonach die Variation der mittleren Schneedichte an Hängen von der semi-stabilen zonalen Verteilung der bodennahen Lufttemperatur abhängig ist.

\section{INTRODUCTION}

Processes controlling the densification of snow have been the subject of a considerable research effort in the past. This is in part a reflection of the importance of density in determining the reaction of the snow to external and internal stresses and gradients, and the close relationship which exists between snow density and the environment in which it develops. Sorge (1938) proposed that snow density could be considered an environmental indicator and in recent years this property has been related to virtually every environmental parameter with varying degrees of success. Schytt (1958) has discussed wind and temperature as being the two most important factors. Sorge (Bader, 1954) and later Benson (1962) suggested that, in the absence of melt, overburden pressure became the dominant process. Langway ( $196 \mathrm{I}$ ) correlated average snow density in northern Greenland with elevation, accumulation and temperature, while Taylor ( $1_{965}$ ) has empirically related this property to latitude in the vicinity of the South Pole.

The above has been interpreted to indicate that the average values of certain index properties of the snow pack may be related to the average intensity of those environmental factors capable of modifying the process of snow metamorphism. In view of the largely irreversible nature of many of the metamorphic processes operating in the snow pack, it is suggested that the effect of those processes will be evident in accumulation increments ranging from that deposited from several storms during a single season through a number of annual layers. This increment will be determined by the depth to which any given environmental influence can penetrate into the pack and its significance as a metamorphic process.

There have been two approaches to the study of snow metamorphism in response to

* Present address: Environmental Research Group, Electronics Research Laboratory, Montana State University, Bozeman, Montana, U.S.A. 
environmental factors as a field problem in the past. One has been to analyze the stratigraphy of the snow pack along a traverse line using pits dug at selected intervals and to relate the measured variations in snow properties from pit to pit to actual or assumed changes in environmental factors along the same line. The best example of this approach is found in Benson (1962). Another approach has been to conduct snow studies at a single site and to measure temporal variations in the various properties. Studies such as those by Bader and others (1939) are a good example of this method. Due to obvious logistic considerations, the traverse technique has been used most successfully on the Greenland and Antarctic Ice Sheets, while the site study has been applied to the study of alpine snow where terrain complicates movement from one site to another. The studies discussed in the present paper are the outgrowth of an attempt by the author and others at the U.S. Army Cold Regions Research and Engineering Laboratory to adapt the traverse technique to a study of alpine snow.

It is the purpose of this paper to present one aspect of the results obtained from two traverses in alpine areas and to discuss the assumed significance of the systematic changes of average snow density with elevation which were found to exist along both traverse lines. The data are presented primarily in graphical form and only the most obvious conclusions are drawn. It is felt that the primary need of research into facets of the alpine environment at the present time is direction in the form of a preliminary hypothesis and the development of practical research approaches. It is to these ends that this paper is specifically directed.

\section{Location and Nature of the Research Sites}

\section{Beartooth Mountains}

This range lies in south-western Montana between lat. $45^{\circ} \mathrm{oo}^{\prime}$ and $45^{\circ} 30^{\prime} \mathrm{N}$., and long. $109^{\circ}$ and $110^{\circ} \mathrm{W}$. A traverse of $12 \mathrm{~km}$. was made on the south flank of the range between Cooke City, Montana $(2,350 \mathrm{~m}$.), and Star Lake $(2,890 \mathrm{~m}$.). The location of the traverse line and pit locations are shown in Figure r. A detailed description of the general area has been given by Alford and Weeks (1965). The terrain along the line of the traverse consists of a gently rolling glaciated upland, timbered to an elevation of approximately $2,500 \mathrm{~m}$., above which trees exist in scattered groups to the timber line at approximately $2,850 \mathrm{~m}$. Experience during the springs of 1964 and 1965 indicates that, while the prevailing wind at the surface during the day is from the south at an elevation of $2,980 \mathrm{~m}$., major storms invariably move into the range from the north, making the slope on which the traverse line was located a lee slope in terms of accumulation. Pronounced development of sastrugi was noted at Goose Lake $(2,980 \mathrm{~m}$.) and Long Lake $(2,840 \mathrm{~m}$.) during the 1964 and 1965 field seasons but the remainder of the traverse line appeared to be unaffected by surface wind.

\section{Mount Logan, St. Elias Range}

This range lies between lat. $60^{\circ}$ and $6 \mathrm{I}^{\circ} \mathrm{N}$., and long. $138^{\circ}$ and $142^{\circ} \mathrm{W}$. on the YukonAlaska boundary. A $16 \mathrm{~km}$. traverse was made on the west flank of Mount Logan (6,050 m.) from 2,280 m. on the upper Ogilvie Glacier to 4,500 m. at King Col (Fig. 2). All of the pits but one were dug in the snow and firn of the King Trench which, with the exception of one small ice fall at between 3,600 and 3,900 m., possesses an extremely uniform gradient of from 5 to $10^{\circ}$ throughout its entire length. During June 1965 the near-surface wind direction was continuously down-glacier. Features associated with marked surface-wind scour were most pronounced immediately below the ice fall mentioned above, at an elevation of approximately $3,600 \mathrm{~m}$. These died out above and below that point to become completely non-existent within a vertical distance of $400 \mathrm{~m}$.

\section{Research Techniques}

The density values discussed in this paper were obtained with the standard SIPRE 


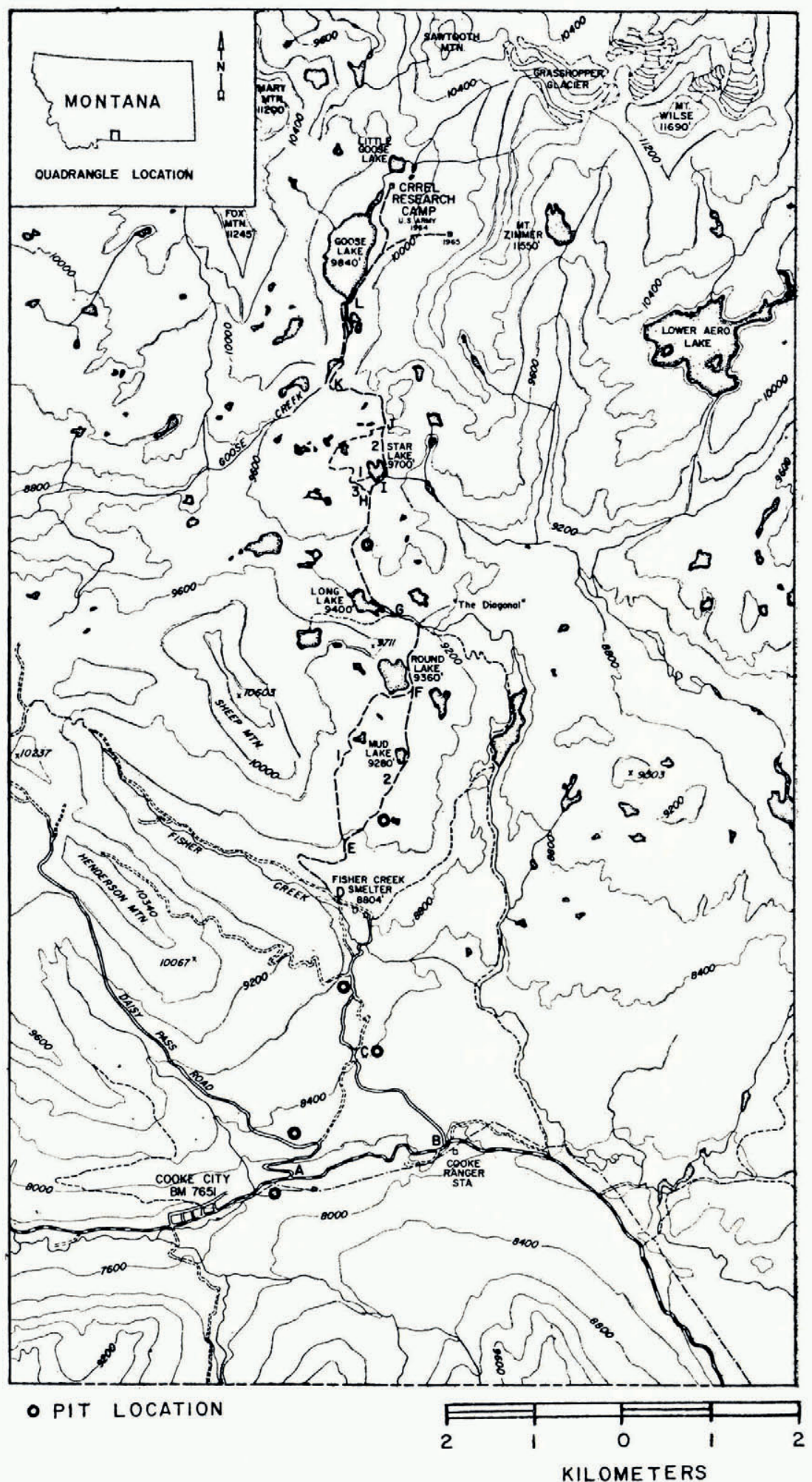

Fig. I. A map of part of the southern flank of the Beartooth Mountains, south-western Montana, showing the location of the traverse line and pit locations 


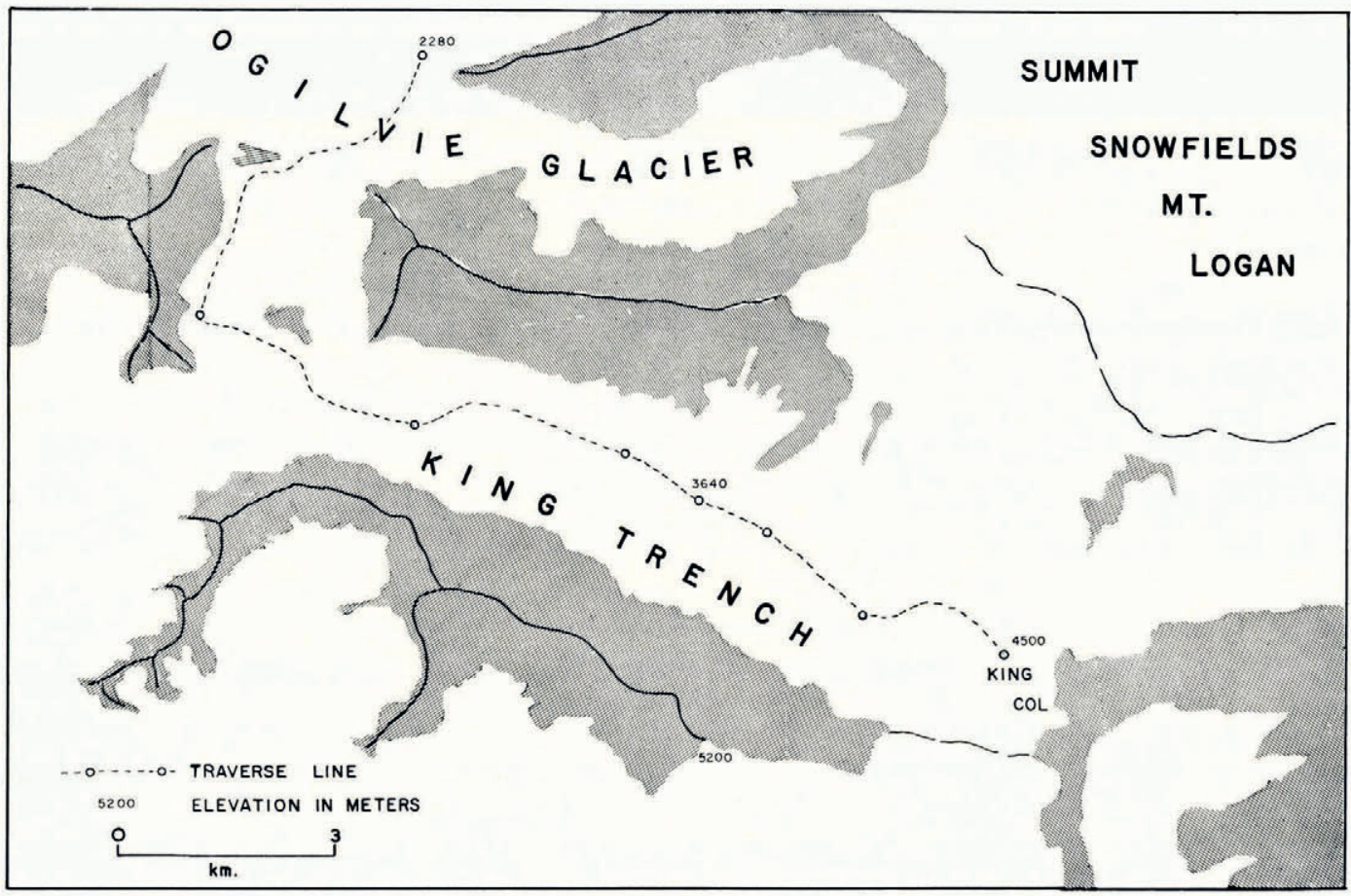

Fig. 2. The King Trench on the west flank of Mount Logan in Canada's St. Elias Range, showing the traverse line and pit locations

snow-density kit, which consists of $12500 \mathrm{~cm} .3$ stainless-steel tubes with rubber caps, a spring balance graduated in grams and two trimming plates. Individual density values were measured at $5^{-10} \mathrm{~cm}$. intervals down each pit wall as measured with a steel tape hung from a board resting on the surface of the snow pack. Bader (1962) has stated that with care an accuracy of $0.005 \mathrm{~g} . / \mathrm{cm} .{ }^{3}$ can easily be obtained by this method. The average density values were obtained by integrating the individual measurements at each site over the depth of the pit and these values are assumed to have a relative accuracy of $0.005 \mathrm{~g} . / \mathrm{cm} .^{3}$.

On the Beartooth Mountains traverse, pits were dug at vertical intervals of approximately $120 \mathrm{~m}$. Pit locations were determined by triangulation with a Brunton pocket transit and elevations were taken from the U.S. Geological Survey Cooke City, Montana-Wyoming quadrangle map ( $\mathrm{i}: 62,500)$ with a contour interval of $80 \mathrm{ft} .(24 \cdot 4 \mathrm{~m}$.).

On Mount Logan, pits were dug at vertical intervals of approximately $300 \mathrm{~m}$. Pit locations were estimated from vertical aerial photographs (approximate scale of $i: 63,000$ ) and the Mount St. Elias sheet of the Canadian Department of Mines and Technical Surveys ( $1: 250,000$ ). Elevations were taken from this same map and, while absolute accuracy is undoubtedly low, relative accuracy is felt to be within $30 \mathrm{~m}$. Aircraft landings were made at the sites of pits I, 2 and 3, affording an opportunity to check the altimeter of the aircraft against the estimates made from the map. In all cases, the agreement was within the above value.

\section{Results}

The distribution of average snow density along each traverse line as function of elevation is shown in Figure $3 a$ and b. It can be seen that the distribution in each area is similiar, with 
the highest value measured near the elevational mid-point of each traverse line and decreasing in both directions from that point to minimum values at the elevation extremes of the traverse.

Total accumulation obtained from the density measurements and expressed in $\mathrm{g} . / \mathrm{cm} .{ }^{2}$ is shown plotted against elevation in Figure $4 \mathrm{a}$ and $\mathrm{b}$. In both areas, the general trend of the accumulation is towards increasing values at higher elevations. The secondary maximum on the Mount Logan curve is believed to be the product of drifting from the zone of intense wind scour at $3,600-3,900 \mathrm{~m}$.

Snow temperatures measured at a depth of $\mathrm{I} \cdot 50 \mathrm{~m}$. on the Mount Logan traverse and at I $\mathrm{m}$. on the Beartooth Mountains traverse are plotted against elevation in Figure $5 \mathrm{a}$ and b. In the case of the Mount Logan data, a depth of $\mathrm{I} \cdot 50 \mathrm{~m}$. was selected as this was the depth of the shallowest pit. While temperatures this close to the surface cannot be compared with the mean annual temperature, it is felt that they can be used to provide some insight into the air-temperature lapse-rate prevailing along the slope during the period of investigation. Temperatures are not given for the lowest pits on the traverse line due to the initiation of spring melt at their elevations. The temperatures shown for the Beartooth Mountains traverse are those measured in the coldest part of the snow pack. Because this snow cover is seasonal, temperatures at its base will be modified by heat introduced from the underlying ground. It will therefore be less strongly affected by variations in air temperature. Unpublished data from a site study of the Beartooth Mountains snow pack obtained at the Goose Lake research station immediately prior to the traverse indicate that diurnal airtemperature variations were largely damped out at a depth of $\mathrm{I} \cdot \mathrm{oo}$ to $\mathrm{I} \cdot 5 \mathrm{O} \mathrm{m}$., at which depth the coldest temperatures of the snow pack were measured. These temperatures were
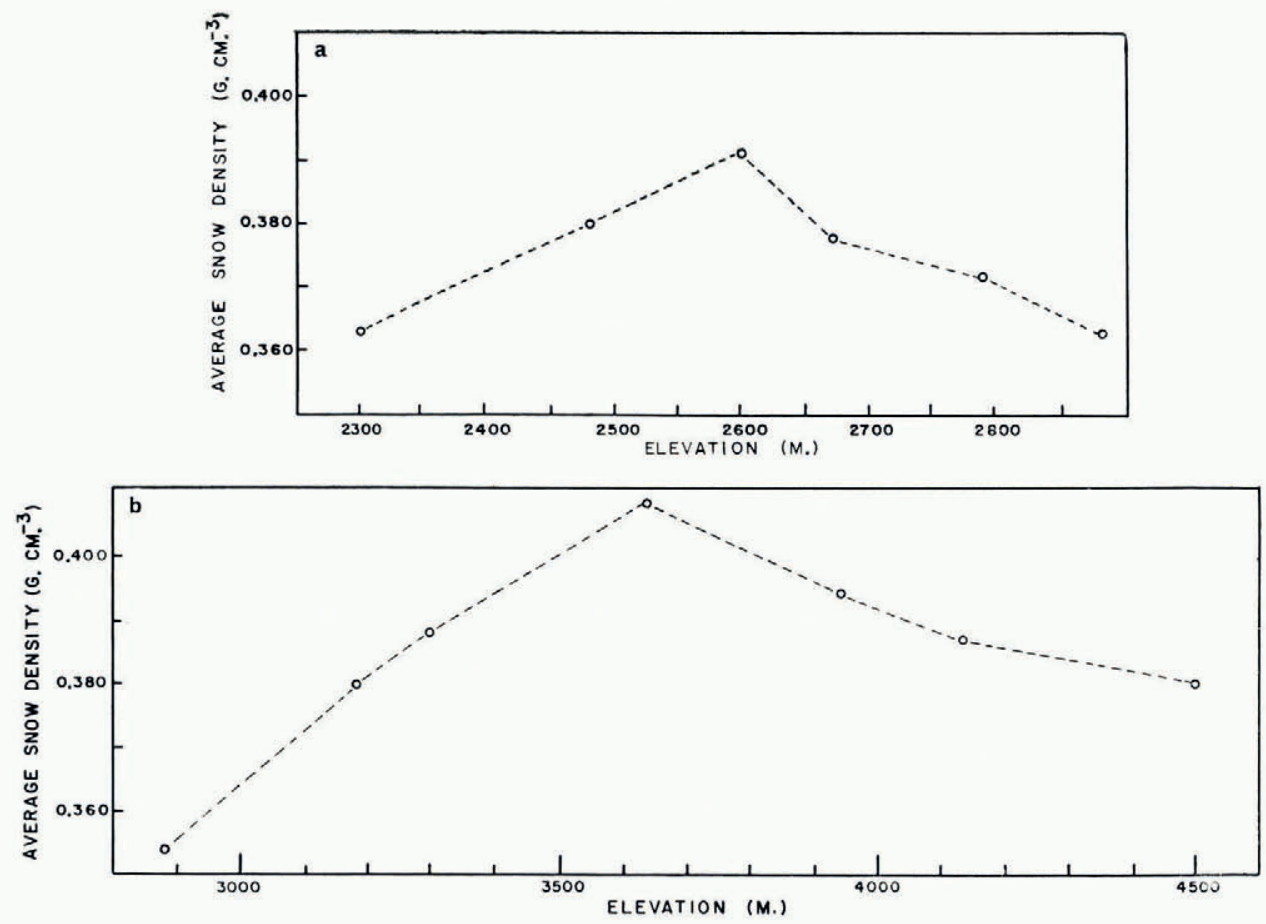

Fig. 3. a. Average snow density vs. elevation along the Beartooth Mountains traverse line; April 1965. $b$. Average snow density vs. elevation along the Mount Logan traverse line; June 1965 

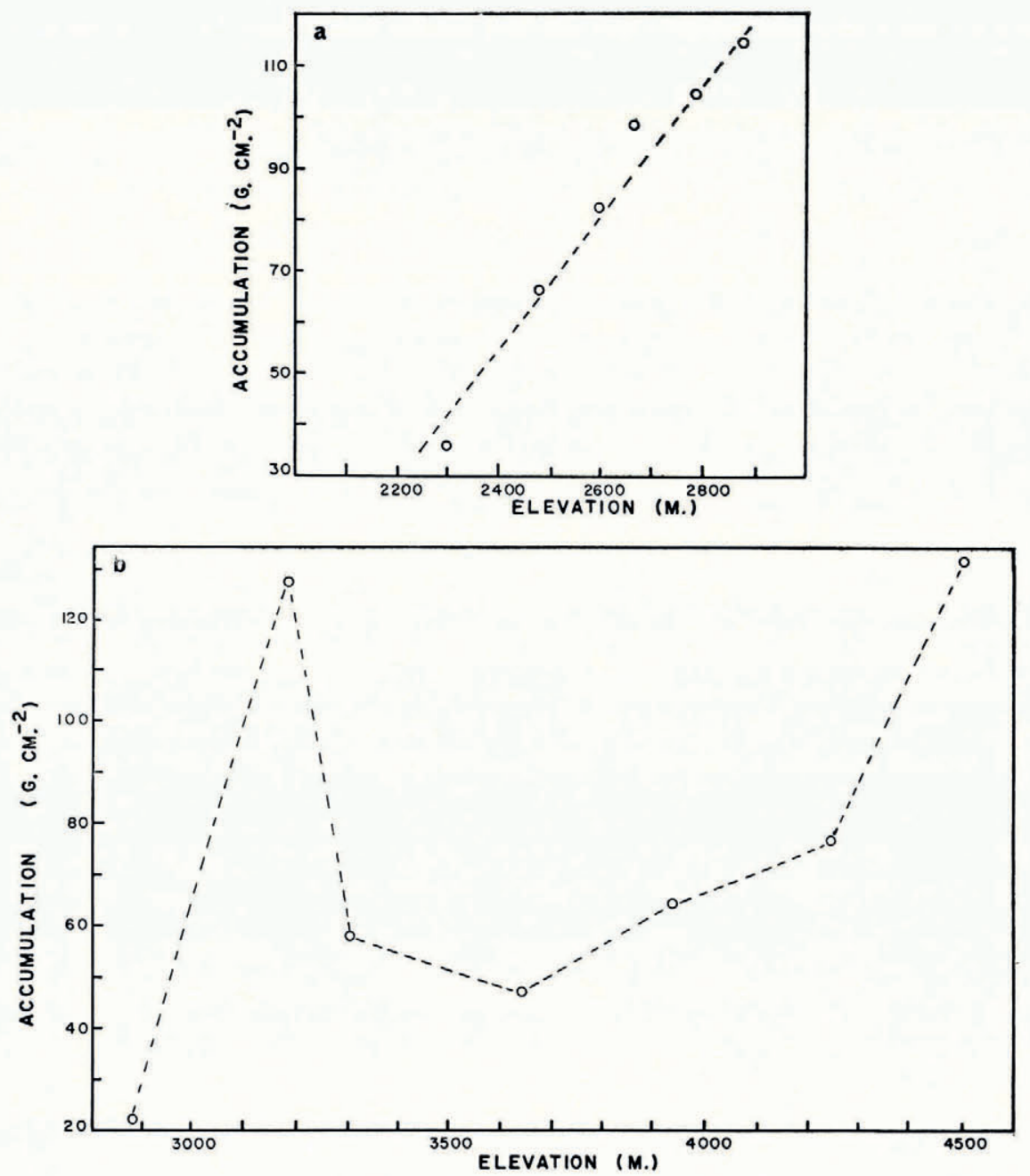

Fig. 4. a. Accumulation vs. elevation; Beartooth Mountains traverse line; April 1965. b. Accumulation vs. elevation; Mount Logan traverse line; 7 une 1965

measured on the assumptions that they were primarily the product of an atmospheric heat source and that they were sufficiently stable to allow pit to pit correlations during the time required to complete the traverse (approximately one week). In the case of the Beartooth Mountains traverse also, temperatures from the two lowest pits are not included, as both had been modified by percolating melt water.

\section{Discussion of Results and Conclusions}

From a purely mechanical standpoint, processes of densification fall into three categories based on temperature, wind speed and overburden pressure. Models relating metamorphism to latitude, longitude, elevation, age, etc. must, in the final analysis, be reducible to one of those three. In view of the inter-related nature of temperature and accumulation, and the influence of wind on both of these, it is difficult to discuss the effect of one independently of 

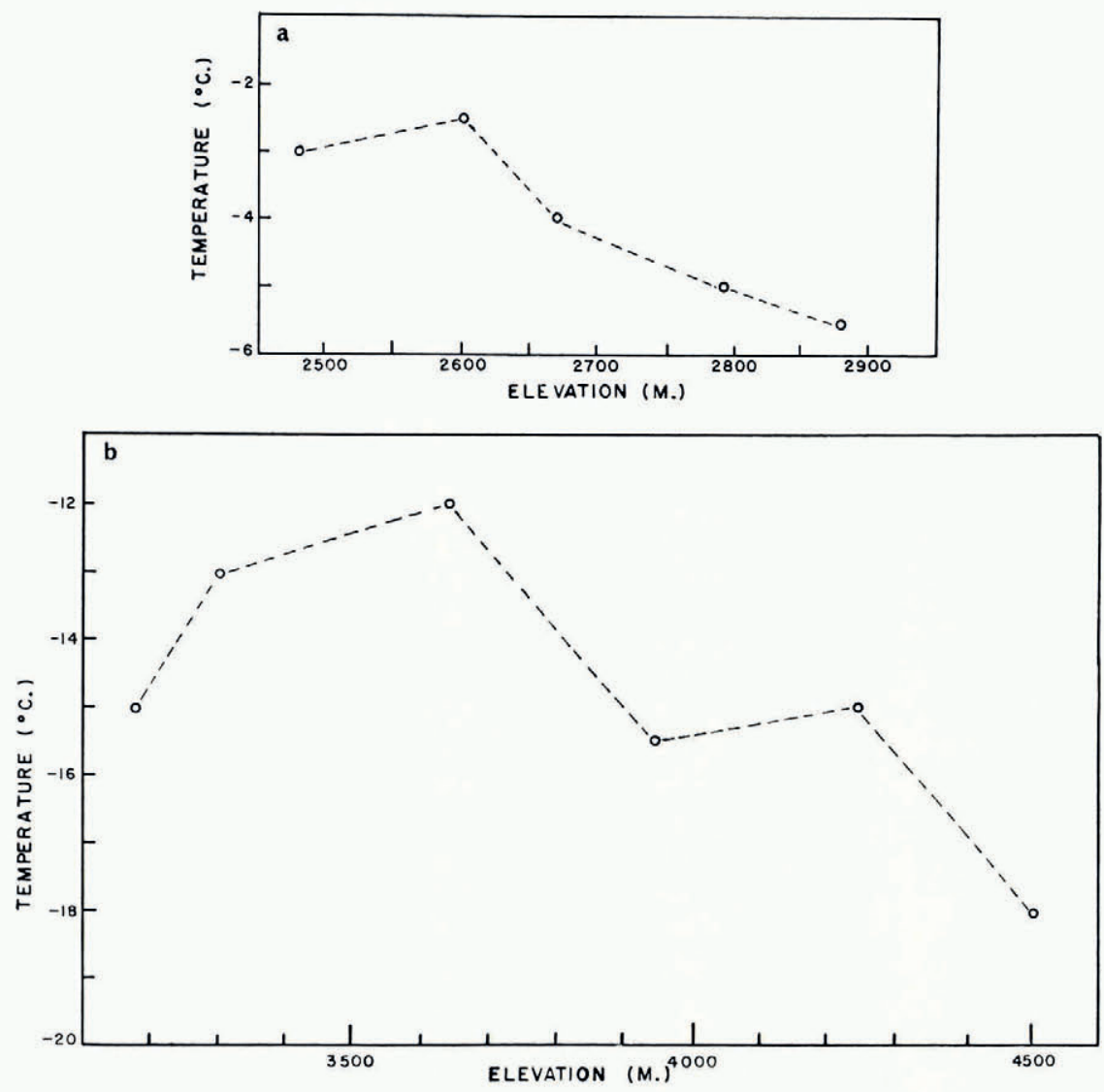

Fig. 5. a. Snow temperatures measured at a depth of $I .50 \mathrm{~m}$. vs. elevation; Mount Logan traverse; 7une 1965.6 . Snow temperatures of the coldest part of the snow pack vs. elevation; Beartooth Mountains traverse line; April 1965

the others on the basis of evidence provided by field data. In the analysis of the data presented above, a number of arbitrary assumptions were made. It was assumed that the variations in the average density of the annual snow layer were produced principally by a single process and that the intensity of this process varies along the traverse line in the same fashion as the density values. While the average density value at any given pit is undoubtedly the result of an interaction between wind, temperature and accumulation, it is unreasonable to assume that the three will maintain a constant relationship at all points on any traverse line. The only one of the three processes which appears to have a distribution similiar to that of the average density values on both traverse lines is temperature. On the basis of the Mount Logan data alone, it can reasonably be argued that the density values are related to both wind and accumulation as well, inasmuch as the maximum density was measured in a zone of intense wind action and at a point of inflexion on the accumulation curve. Combining the data from the two traverses, however, indicates that only the density and temperature curves remain directly related. More recent work by the author which is the subject of a separate communication has shown that a zonation of near-surface minimum air temperatures parallels the distribution of average snow-pack densities along the Beartooth Mountains traverse line. This temperature distribution is shown in Figure 6. While this cannot be considered conclusive evidence for the relationship proposed above, it does indicate that the 


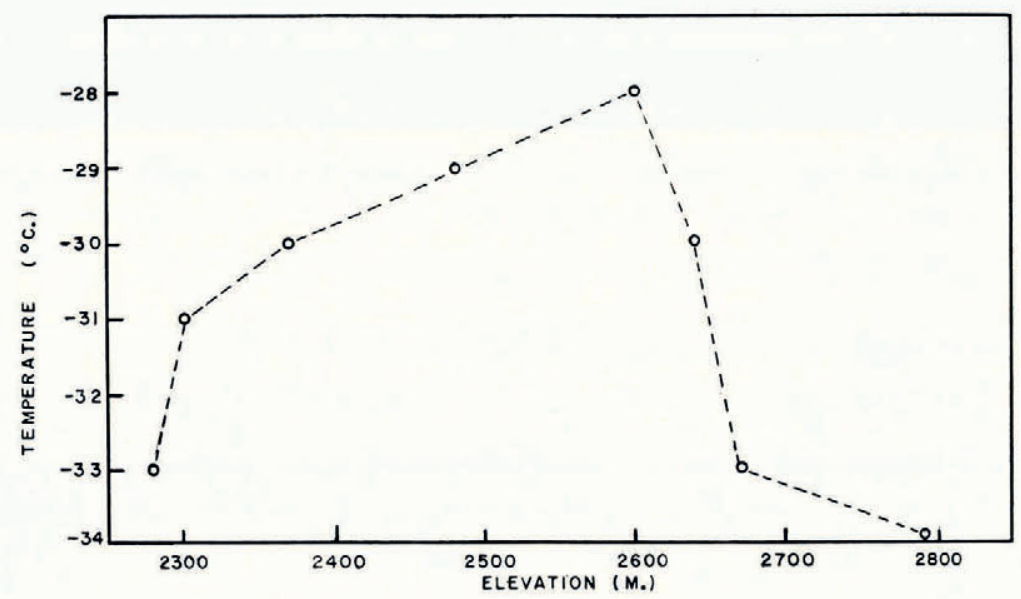

Fig. 6. Average minimum diurnal air temperatures measured at a height of $1 \cdot 50 \mathrm{~m}$. above the snow surface vs. elevation; Beartooth Mountains traverse line; $14^{-17}$ February 1966

near-surface temperature zonation over mountain slopes discussed by Geiger (1965, p. $367-467)$ is a factor in the winter alpine environment.

By relating the density variations directly to temperature, it is possible to explain their distribution in terms of a simple model. Wexler (1936) has suggested that inversions of the normal air-temperature lapse-rate are a common feature over snow-covered surfaces, particularly in polar-continental air masses. These inversions tend to be quite stable and persistent. Geiger ( 1965 , p. $367-467$ ) has shown that an inversion of the normal airtemperature lapse-rate is a semi-stable phenomenon immediately above alpine slopes which lack a snow cover. From this, it is reasonable to assume that snow-covered slopes also exhibit this inverted lapse-rate. On this basis, the point of inflexion on the average snow densityelevation curves can be interpreted as the elevation of the mean winter depth of the inversion layer above and below which air temperatures decrease, and the amount of heat available to promote densification of the pack becomes less. The depth of this inversion will be controlled primarily by topography. It is quite probable that more complex topography than that encountered on the two traverses discussed here will result in more complex densityelevation curves. Long undulating slopes may develop a series of density maxima in response to a series of "stacked" inversions along the slope due to impeded cold-air drainage. The sub-parallelism of the measured snow- and air-temperature lapse rates above the point of inflexion to the dry adiabatic rate of $\mathrm{I}^{\circ} \mathrm{C}$./ $\mathrm{I} 00 \mathrm{~m}$. suggests that these rates may result in part from a warming of katabatic air drainage along the slope.

This paper is the result of a pilot study designed to determine the value of snow stratigraphy analyses as an approach to a better understanding of the alpine environment. Due primarily to problems of accessibility, little is known about the winter environment which exists in large mountain ranges and yet the influence of this environment will become an increasingly significant problem as man's activities in the mountains increase. A complete understanding of glacial hydrology cannot be gained until the depositional environment of the annual snow layer is studied in more detail than is presently the case. It is felt that the results obtained in the present case present the possibility that the annual snow layer may be used as an environmental indicator and that a refinement of these studies will allow valid correlations concerning variations in this environment to be drawn, not only within a single mountain range but between separate mountain ranges. 


\section{Acknowledgements}

These studies were made while the author was employed by the U.S. Army Cold Regions Research and Engineering Laboratory, Hanover, New Hampshire, U.S.A. A preliminary draft of this paper was read by Dr. Carl Benson, Geophysical Institute, University of Alaska, and Dr. Chester Langway, U.S. Army Cold Regions Research and Engineering Laboratory, and the author is indebted to them for their constructive comments. The opinions expressed here, however, are the sole responsibility of the author.

The air-temperature studies along the Beartooth Mountains traverse line were made possible by funds provided by Dr. W. H. Mathews, Department of Geology, University of British Columbia, Vancouver, Canada. Steve Toth, Charlie Keeler, Peter Lev and George Denton, the author's co-workers during various periods of this investigation, deserve particular thanks.

MS. received I April 1966

\section{REFERENCES}

Alford, D. L., and Weeks, W. F. 1965. Accessibility, logistics and field techniques, Goose Lake, Montana. U.S. Cold Regions Research and Engineering Laboratory. Special Report 77.

Bader, H. 1954. Sorge's law of densification of snow on high polar glaciers. Journal of Glaciology, Vol. 2, No. 15, p. 319-23.

Bader, H. I962. The physics and mechanics of snow as a material. U.S. Cold Regions Research and Engineering Laboratory. Cold regions science and engineering. Hanover, N.H., Pt. II, Sect. B, p. I-6o.

Bader, H., and others. I 939. Der Schnee und seine Metamorphose, von H. Bader, R. Haefeli, E. Bucher, J. Neher, O. Eckel, C. Thams, P. Niggli. Beiträge zur Geologie der Schweiz. Geotechnische Serie. Hydrologie, Lief. 3. [Translated by J. C. van Tienhoven, U.S. Snow, Ice and Permafrost Research Establishment. Translation 14, 1954.]

Benson, C. S. 1962. Stratigraphic studies in the snow and firn of the Greenland Ice Sheet. U.S. Cold Regions Research and Engineering Laboratory. Research Report 70.

Geiger, R. 1965. The climate near the ground. Cambridge, Mass., Harvard University Press.

Langway, C. C., jr. I96r. Accumulation and temperature on the inland ice of north Greenland, r959. Journal of Glaciology, Vol. 3, No. 30, p. 101 7-44.

Schytt, V. 1958. Glaciological investigations in the Thule ramp area. U.S. Snow, Ice and Permafrost Research Establishment. Research Report 28.

Sorge, E. 1938. Die Firnschrumpfung in den obersten Schichten des grönländischen Inlandeises. Union Internationale de Géodésie et Géophysique. Association Internationale d'Hydrologie Scientfique. Sixième assemblée générale à Édimbourg, 1936. Compte-rendus et mémoires des Commissions des Neiges et des Glaciers, p. 725-31.

Taylor, L. D. 1965 . Glaciological studies on the South Pole traverse, 1962-1963. Ohio State University. Institute of Polar Studies. Report No. 17.

Wexler, H. I 936 . Cooling in the lower atmosphere and the structure of polar continental air. Monthly Weather Review, Vol. 64, p. 122-36. 